\title{
Effect of Nitrification Inhibitor and Cutting Heights on Degradability of Pearl Millet
}

\author{
Daniel Staciarini Corrêa ${ }^{1}$, Aldi Fernandes de Souza França ${ }^{1}$, Roberto Toledo de Magalhães ${ }^{2}$, Emmanuel Arnhold ${ }^{1}$, \\ Adesvaldo José e Silva Júnior ${ }^{1} \&$ Leonardo Guimarães Oliveira ${ }^{1}$ \\ ${ }^{1}$ Escola de Veterinária e Zootecnia, Universidade Federal de Goiás (UFG), Goiânia, GO, Brazil \\ ${ }^{2}$ Departamento de Zootecnia, Pontifícia Universidade Católica de Goiás (PUC Goiás), Goiânia, GO, Brazil \\ Correspondence: Daniel Staciarini Corrêa, Escola de Veterinária e Zootecnia, Universidade Federal de Goiás \\ (UFG), Rua S-4, n. 452, ap. 604, Setor Bela Vista, Goiânia, GO 74.823-450, Brazil. Tel: 55-62-99614-4532. \\ E-mail: daniel.staciarini@terra.com.br
}

Received: May 15, 2017

Accepted: June 14, $2017 \quad$ Online Published: July 15, 2017

doi:10.5539/jas.v9n8p106

URL: https://doi.org/10.5539/jas.v9n8p106

\begin{abstract}
Pearl millet crop has been increasingly growing in Brazilian Savanna and it is already being used as cover crop between annual crops. The plant has great forage potential, besides being a nutrient recycling plant due to its peculiar root system. This study was developed in order to assess the pearl millet nutritional value when submitted to nitrogen fertilizer. It was evaluated the effect of nitrogen fertilizer (ammonium sulfate nitrate) treated with the nitrification inhibitor 3,4-dimethyl pyrazole phosphate (DMPP) on the ruminal degradability of two pearl millets' cultivars, under four nitrogen fertilization levels $\left(0,45,90\right.$ and $\left.180 \mathrm{~kg} \mathrm{ha}^{-1}\right)$ and pre-cutting heights $(0.70,0.80$ and $0.90 \mathrm{~m})$. The experimental design was a randomized block design in a factorial $3 \times 4(3$ cutting heights $\times 4$ nitrogen doses) with three replications. Data were submitted to analysis of variance and means were compared by Tukey test at $5 \%$ probability. The DMPP treated Nitrogen, in high doses, increased the dry matter, crude protein and neutral detergent insoluble fiber degradability in pearl millet handled at $0.90 \mathrm{~m}$. The combination of fertilization with 45 or $90 \mathrm{~kg} \mathrm{ha}^{-1}$ of nitrogen treated with DMPP, with the management of millet at 0.70 or $0.80 \mathrm{~m}$ did not favored the forage nutritional quality, indicating that in these treatments, the ratio between the availability of nitrogen in ammonium and nitrate forms may have been detrimental to the plants.
\end{abstract}

Keywords: nitrogen fertilization, nutritive value, pre-cutting height, Pennisetum glaucum, ruminal degradation, slow release fertilizer

\section{Introduction}

Given the great economic importance of bovine farming for the State of Goiás, the pressure for higher productivity allied with environmental conservation and the high impact that nitrogen fertilization causes on these factors (increased production and risks to the environment), it becomes very important to have the information on the response of forage plants, in terms of nutritional value, face to the application of nitrogen fertilizers.

The use of Pearl millet as forage is increasing in the last decades, due to its utility as soil coverage in the conventional and no-tillage cropping systems.

The Pearl millet (Pennisetum glaucum (L.) R. Brown) emerged between 4000 and 5000 years ago, in the south of the Sahara Desert and has, as highlights, a highly developed root system, which makes it able to absorb nutrients at depth and recycle them, as well as being a water stress tolerant crop, with high potential for green mass production (Empresa Brasileira de Pesquisa Agropecuária [EMBRAPA], 2014).

The evaluation of the nutritional value of feed must take into account, in addition to its chemical-bromatological composition, the ability of the animal to take advantage of the nutrients present in that food. Among the various techniques that can be used to determine the nutritional performance, the in situ technique stands out for its low cost and high correlation with in vivo experimentation (Nocek, 1988), besides allowing the evaluation of several foods at the same time, or the same food submitted to different treatments, and also does not demand large quantity of animals and does not require special equipment such as metabolic cages or gas chambers (Brito et al., 2007). 
The effect of nitrogen fertilization on forage is widely reported, as well as the great nutrient losses after fertilizer application. According to Cameron, Di, and Moir (2013), in the agroecosystems the mineral-N losses occur mainly due to ammonia volatilization, leaching and transformations into gaseous forms.

One way to reduce these losses is to use fertilizers of low liberation.

Among the mechanisms to reduce losses of nitrogen fertilizer, there is the use of nitrification inhibitors, used to prevent ammonium nitrification $\left(\mathrm{NH}_{4}{ }^{+}\right)$. According to Gilsanz et al. (2016) the nitrification inhibitors deactivate the enzyme responsible for the oxidation of $\mathrm{NH}_{4}{ }^{+}$to $\mathrm{NO}_{2}{ }^{-}$(nitrite). The nitrite will be transformed into nitrate $\left(\mathrm{NO}_{3}{ }^{-}\right)$(denitrification) by the Nitrobacter and Nitrosolobus bacteria (Trenkel, 1997). Nitrate is the initial substrate for denitrification (Gilsanz et al., 2016). Thus, the use of nitrification inhibitor will delay both the nitrification and the denitrification processes. During the nitrification process, nitric oxide (NO) and nitrous oxide $\left(\mathrm{N}_{2} \mathrm{O}\right)$ are produced, which are two highly volatile gases, and nitrous oxide is a greenhouse gas whose global warming potential corresponds to 296 times the heating potential of carbon dioxide $\left(\mathrm{CO}_{2}\right)$ (Intergovernmental Panel on Climate Change [IPCC], 2001). Chen et al. (2010) verified, in a 42 days trial, that the use of nitrification inhibitors (DMPP or N-serve) reduced the $\mathrm{N}_{2} \mathrm{O}$ emissions by 93 and $98 \%$, respectively, when compared with nitrogen fertilizer (Urea) without nitrification inhibitors at $25{ }^{\circ} \mathrm{C}$ and humidity of $60 \%$ water filled pore space (WFPS); while Menéndez et al. (2012) evaluated the DMPP effect during 51 days and observed, at $20{ }^{\circ} \mathrm{C}$ and $80 \%$ WFPS, a reduction on $\mathrm{N}_{2} \mathrm{O}$ emission of $23 \%$ when compared with ammonium sulfate nitrate without DMPP.

The main advantage of inhibiting the nitrification process is that the ammonium ion strongly adheres to the soil particles, avoiding losses through leaching. Gilsanz et al. (2016) states that including nitrification inhibitors at any $\mathrm{NH}_{4}{ }^{+}$-based $\mathrm{N}$ source, such as urea or other organic fertilizers, which subsequently convert to $\mathrm{NH}_{4}{ }^{+}$will retain the $\mathrm{N}$ in the soil in the $\mathrm{NH}_{4}{ }^{+}$form for longer. This occurs because nitrification inhibitors minimizes the concentration peaks of $\mathrm{NO}_{3}{ }^{-}$in soil, reducing the potential for $\mathrm{N}$ losses by denitrification or $^{\mathrm{NO}_{3}}{ }^{-}$leaching (Gilsanz et al., 2016).

On the other hand, the exclusive absorption of $\mathrm{NH}_{4}{ }^{+}$can be harmful to the plants. According to Britto \& Kronzucker (2013) the ammonium build-up can disturb the uptake of important cationic nutrients, such as $\mathrm{K}^{+}$, $\mathrm{Ca}^{2+}$ and $\mathrm{Mg}^{2+}$. In some crops, there is a negative effect of the $\mathrm{NH}_{4}{ }^{+}$ion on growth, and this is attributed to the need to use the carbohydrates produced, primarily, for the rapid assimilation of the absorbed ammonium, in order to avoid its accumulation and consequent toxicity problems related to changes in cellular $\mathrm{pH}$ and ionic imbalance (Britto \& Kronzucker, 2002). The reduction in growth occur because an elevated supply of carbohydrate is allocated to the roots (Britto \& Kronzucker, 2013).

This paper aimed to evaluate the in situ degradability of Pearl millet (BRS 1501 and ADR 500) at three different heights in cutting regime, submitted to four doses of nitrogen (ammonium sulfonitrate) treated with nitrification inhibitor (3,4-dimethyl pyrazole phosphate - DMPP). The cultivar BRS 1501 is a double purpose cultivar, while ADR 500 is a fodder production cultivar. Both cultivars are among the most selling in Brazil and are specially recommended for the Cerrado (Brazilian Savanna) region.

\section{Materials and Methods}

This study was approved by the Committee of Ethics in the Use of Animals (CEUA) and is registered under No. $116 / 14$.

\subsection{Field Experiment}

The field experiment was conducted in Goiania municipality, with latitude $16^{\circ} 35^{\prime} \mathrm{S}$, longitude $49^{\circ} 16^{\prime} \mathrm{W}$ and altitude of $727 \mathrm{~m}$. The regional climate is from Aw type, warm and semi-humid, with a dry season from May to October and a wet season between November and April, with an annual mean temperature of $23.2^{\circ} \mathrm{C}$ (Ministério da Agricultura Pecuária e Abastecimento [MAPA], 1992). The temperature and rainfall data from the experimental period, which was from December $21^{\text {st }}, 2012$ to May $04^{\text {th }}, 2013$, are presented in Figure 1. 


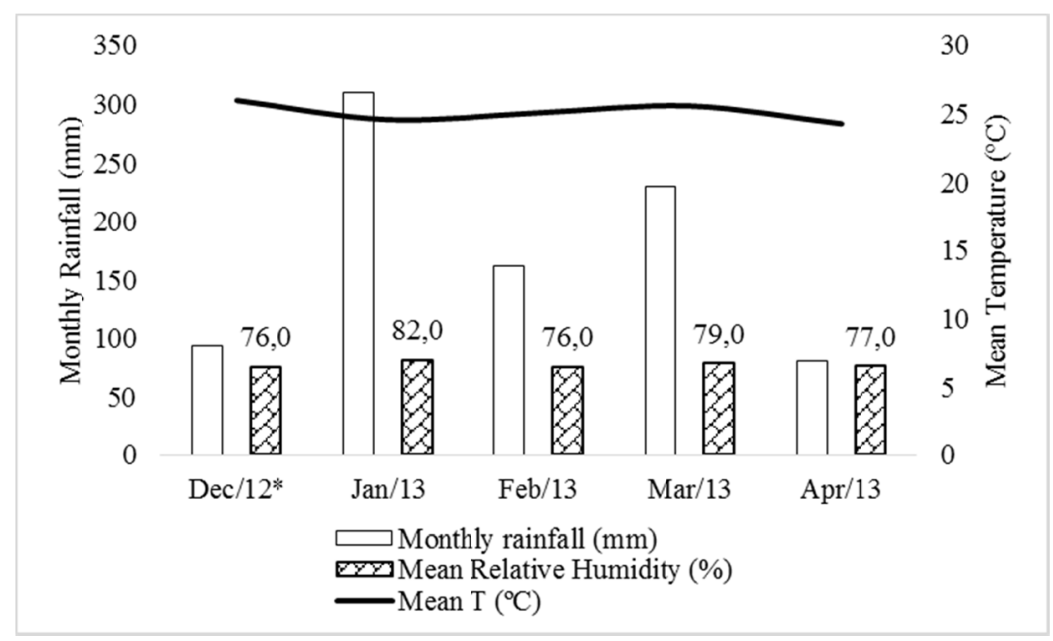

Figure 1. Temperature and rainfall during the experimental period

Note. *Data from December 2012 refer only to the period 12/21/2012-12/31/2012.

Source: Evaporimetric Station of the Agronomy School-Universidade Federal de Goiás.

The sowing occurred in December $21^{\text {st }}, 2012$, and the results of the soil analysis of the experimental area are showed in Table 1.

Table 1. Results from soil analysis from experimental area

\begin{tabular}{|c|c|c|c|c|c|c|c|c|c|c|c|c|}
\hline Clay & Silt & Sand & $\mathrm{OM}$ & V & $\mathrm{pH}$ & P (Mehl) & $\mathrm{K}$ & $\mathrm{Ca}$ & $\mathrm{Mg}$ & $\mathrm{H}+\mathrm{Al}$ & $\mathrm{Al}$ & CEC \\
\hline$-\cdots$ & - & $\%$ &.-- & --- & $\mathrm{CaCl}_{2}$ & ----- mg & 3----- & ---- & ----- & $\mathrm{mol}_{\mathrm{c}} \mathrm{dr}$ & 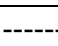 & 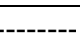 \\
\hline 35.0 & 19.0 & 46.0 & 1.8 & 5.9 & 35.0 & 3.8 & 69.0 & 3.4 & 1.1 & 2.8 & 0.0 & 7.5 \\
\hline
\end{tabular}

Note. $\mathrm{OM}=$ Organic matter; $\mathrm{V}=$ Base saturation; $\mathrm{CEC}=$ Cation exchange capacity at $\mathrm{pH}$ 7.0.

The treatments consisted of two Pearl millet cultivars (Pennisetum glaucum (L.) R. Brown) (cv. ADR-500 and BRS-1501); four nitrogen doses $\left(0 ; 45 ; 90\right.$ and $\left.180 \mathrm{~kg} \mathrm{ha}^{-1}\right)$ in the ammonium sulfonitrate form, treated with nitrification inhibitor (3,4-dimethyl pyrazole phosphate - DMPP), and three pre-cut heights $(0.70 ; 0.80$ and 0.90 $\mathrm{m}$ ). At the time of sowing, $60 \mathrm{~kg} \mathrm{ha}^{-1}$ of $\mathrm{P}_{2} \mathrm{O}_{5}$ (SS), $50 \mathrm{~kg} \mathrm{ha}^{-1}$ of micronutrients (FTE Br 12) and $50 \mathrm{~kg} \mathrm{ha}^{-1}$ of $\mathrm{K}_{2} \mathrm{O}(\mathrm{KCl})$ were applied as formation fertilization, according to the recommendations by Martha Junior, Vilela, and Sousa (2007).

The nitrogen doses were applied only once, at 15 days after emergence of the seedlings. The evaluation cuttings were performed whenever the plots reached the mean evaluation heights $(0.70,0.80$ or $0.90 \mathrm{~m})$. Once the plot reached the desired height, the evaluation cut was made, leaving a residue of $0.20 \mathrm{~m}$ in height.

After cutting, all material collected from the usable area was weighed for evaluation of production by area, and one sample was collected and taken to the laboratory to perform bromatological analysis.

\subsection{Nutritional Value Analysis}

The samples were weighed and pre-dried in a forced ventilation oven $\left(65^{\circ} \mathrm{C}\right)$ for 72 hours. After pre-drying the samples were milled in a "Thomas-Willey" mill, type stationary with $1.0 \mathrm{~mm}$ mesh sieve, and stored in plastic container for future bromatological analysis. Another part of the material was milled in a $5.0 \mathrm{~mm}$ mesh sieve for in situ degradability analysis.

The bromatological analyzes were done by drying the material in a forced ventilation oven at $65^{\circ} \mathrm{C}$, followed by oven at $105^{\circ} \mathrm{C}$, and the dry matter content was determined by weight difference. The crude protein (CP) was determined following the Kjeldhal method (Association of Official Analytical Chemists [AOAC], 1990). The neutral detergent insoluble fiber (NDF) and acid detergent insoluble fiber (ADF) were calculated by the sequential method (Robertson \& Van Soest, 1981). The ethereal extract (EE) was determined by the Soxhlet methodology (Silva \& Queiroz, 2002). 
The fraction of total carbohydrates (CHOt) was calculated in accord with Sniffen, Connor, Van Soest, Fox, and Russel (1992), using the equation:

$$
t C H O=100-(\% C P+\% E E+\% \text { Ashes })
$$

Ruminal degradability was determined using two male bovine (Holstein $\times$ Zebu), castrated, rumen-cannulated, maintained in paddock with access to water, mineral mix and forage ad libitum.

The samples were conditioned in nylon bags with $50 \mu \mathrm{m}$ diameter pores, measuring $5 \times 14 \mathrm{~cm}$ in size, sealed at the edges and properly identified. Three bags, each one containing $5.00 \mathrm{~g}$ of sample were incubated in each animal, for each treatment. The samples were incubated in descending order of time so that they could be removed all at once and the washing could be standardized. After removing the samples from the animal, they were washed in running water until the water ran clear, and then they were dried in an oven at $65{ }^{\circ} \mathrm{C}$ until reaching constant weight. Then, it was determined the ruminal degradability of the constituents.

The degradability equations used were determined from the model proposed by Orskov and McDonald (1979), as it follows:

$$
Y=A+B \times\left(1-e^{-c t}\right)
$$

Where, "A" is the maximum degradation percentage of the material in the nylon bag; "B" is the potentially degradable fraction that would be degraded at a certain rate "c"; "c" is a constant fractional rate of the degradation of the remaining fraction in the nylon bag, and " $\mathrm{t}$ " is the time of incubation in the rumen.

The effective degradability (DE) was calculated according the model proposed by Orskov and McDonald (1979):

$$
D E=A+B \times \frac{c}{c+K}
$$

Where, " $K$ " is the passage rate of small particles obtained after the use of different levels of feed and diets, "A", "B" and "c" are the same parameters of Equation (2).

\subsection{Statistics}

The experimental design was a randomized block design in a $3 \times 4$ factorial arrangement ( 3 cutting heights $\times 4$ doses of $\mathrm{N}$ ) with three replicates each (blocks). The variables were submitted to analysis of variance and the means were compared by the Tukey test at $5 \%$ of probability. Statistical analyzes were performed using statistical software R.

\section{Results and Discussion}

\subsection{Chemical Composition}

The chemical composition of the cultivar BRS 1501 is presented in the Table 2. There was a significant interaction $(\mathrm{P}<0.05)$ between the $\mathrm{N}$ dose and pre-cut heights for the levels of crude protein, acid detergent insoluble fiber and ash, with its unfolding being shown in Table 2. 
Table 2. Mean values of dry matter (DM), crude protein (CP), acid detergent insoluble fiber (ADF), neutral detergent insoluble fiber (NDF), and ash (Ash) from BRS 1501 Pearl millet cultivar, in function of $\mathrm{N}$ dose and pre-cut heights (in \%DM)

\begin{tabular}{|c|c|c|c|c|}
\hline \multirow{2}{*}{$\mathrm{N}$ dose $\left(\mathrm{kg} \mathrm{ha}^{-1}\right)$} & \multicolumn{3}{|c|}{ Cutting Height (m) } & \multirow{2}{*}{ CV (\%) } \\
\hline & 0.70 & 0.80 & 0.90 & \\
\hline \multicolumn{5}{|l|}{$D M$} \\
\hline 0 & $11.02 \mathrm{Ab}$ & $12.95 \mathrm{Ab}$ & $19.86 \mathrm{Aa}$ & 26.55 \\
\hline 45 & $11.30 \mathrm{Ab}$ & $13.49 \mathrm{Ab}$ & $19.16 \mathrm{Aa}$ & \\
\hline 90 & $11.27 \mathrm{Ab}$ & $13.47 \mathrm{Ab}$ & $19.99 \mathrm{Aa}$ & \\
\hline 180 & $10.83 \mathrm{Ab}$ & $12.80 \mathrm{Ab}$ & $20.33 \mathrm{Aa}$ & \\
\hline \multicolumn{5}{|l|}{$C P$} \\
\hline 0 & $10.63 \mathrm{Ba}$ & $10.73 \mathrm{Ba}$ & $9.80 \mathrm{Ca}$ & 7.62 \\
\hline 45 & $8.69 \mathrm{Cb}$ & $10.95 \mathrm{Ba}$ & $10.24 \mathrm{BCa}$ & \\
\hline 90 & $8.24 \mathrm{Cb}$ & $8.68 \mathrm{Cb}$ & $12.61 \mathrm{Ba}$ & \\
\hline 180 & 16.14 Aa & $19.51 \mathrm{Aa}$ & $18.23 \mathrm{Aa}$ & \\
\hline \multicolumn{5}{|l|}{$N D F$} \\
\hline 0 & $75.11 \mathrm{Aa}$ & $76.61 \mathrm{Aa}$ & $72.69 \mathrm{Aa}$ & 4.22 \\
\hline 45 & $75.74 \mathrm{Aa}$ & $69.78 \mathrm{Aa}$ & $76.59 \mathrm{Aa}$ & \\
\hline 90 & $77.58 \mathrm{Aa}$ & $77.44 \mathrm{Aa}$ & $78.65 \mathrm{Aa}$ & \\
\hline 180 & $76.33 \mathrm{Aa}$ & $75.20 \mathrm{Aa}$ & $67.39 \mathrm{Aa}$ & \\
\hline \multicolumn{5}{|l|}{$A D F$} \\
\hline 0 & $30.92 \mathrm{Aa}$ & $32.74 \mathrm{Aa}$ & $27.86 \mathrm{Ba}$ & 7.69 \\
\hline 45 & $30.13 \mathrm{Aa}$ & $27.15 \mathrm{Aa}$ & $31.67 \mathrm{ABa}$ & \\
\hline 90 & $34.72 \mathrm{Aa}$ & $34.46 \mathrm{Aa}$ & $38.31 \mathrm{Aa}$ & \\
\hline 180 & $32.90 \mathrm{Aa}$ & $33.54 \mathrm{Aa}$ & $29.67 \mathrm{ABa}$ & \\
\hline \multicolumn{5}{|l|}{ Ash } \\
\hline 0 & $4.07 \mathrm{Ba}$ & $4.79 \mathrm{Ba}$ & $4.53 \mathrm{Ca}$ & 23.14 \\
\hline 45 & 7.18 Aab & $6.41 \mathrm{ABb}$ & $8.71 \mathrm{Aa}$ & \\
\hline 90 & $7.22 \mathrm{Aa}$ & $6.01 \mathrm{Ba}$ & $6.41 \mathrm{Ba}$ & \\
\hline 180 & $8.51 \mathrm{Aa}$ & $8.04 \mathrm{Aab}$ & $6.70 \mathrm{Bb}$ & \\
\hline
\end{tabular}

Note. For each parameter analyzed, means followed by different letters, in upper case in the same column and lower case in the same row are different according to the Tukey test $(\mathrm{P}<0.05)$.

The dry matter contents were influenced only by the cutting height. At lower heights, it was presented values close to those reported by Buso, França, and Miyagi (2014), ranging from 8.90 to $11.14 \%$, for cultivars ADR 7010, ADR 500 and BRS 1501 cut at $0.70 \mathrm{~m}$, and Silva et al. (2012), which were from 10.53 to $18.15 \%$, depending on the nitrogen dose and the plant cutting age. The crude protein had its highest content when fertilized with $180 \mathrm{~kg} \mathrm{~N} \mathrm{ha}^{-1}$, but even at the lowest levels, it was always above $7.0 \%$, which is a value considered critical to the consumption and development of ruminal microorganisms (Van Soest, 1994).

The NDF contents were not affected by cutting height or nitrogen dose. The levels of FDA varied in the plant harvested at $0.90 \mathrm{~m}$, and levels of ash varied without a defined standard.

The chemical composition of ADR 500 cultivar also showed significant interactions for CP, NDF and FDA. The unfolding of these interactions is in Table 3. 
Table 3. Mean values of dry matter (DM), crude protein (CP), neutral (NDF) and acid detergent fiber (ADF), and ashes (Ash) of the ADR 500 cultivar in function of nitrogen doses and pre-cut heights (in \% MS)

\begin{tabular}{|c|c|c|c|c|}
\hline \multirow{2}{*}{$\mathrm{N}$ dose $\left(\mathrm{kg} \mathrm{ha}^{-1}\right)$} & \multicolumn{3}{|c|}{ Cutting Height (m) } & \multirow{2}{*}{$\mathrm{CV}(\%)$} \\
\hline & 0.70 & 0.80 & 0.90 & \\
\hline \multicolumn{5}{|l|}{$D M$} \\
\hline 0 & $10.96 \mathrm{Ab}$ & $12.68 \mathrm{Ab}$ & $19.30 \mathrm{Aa}$ & 26.34 \\
\hline 45 & $10.73 \mathrm{Ab}$ & $12.94 \mathrm{Ab}$ & $19.35 \mathrm{Aa}$ & \\
\hline 90 & $10.82 \mathrm{Ab}$ & $12.87 \mathrm{Ab}$ & $19.42 \mathrm{Aa}$ & \\
\hline 180 & $10.96 \mathrm{Ab}$ & $12.93 \mathrm{Ab}$ & $19.30 \mathrm{Aa}$ & \\
\hline \multicolumn{5}{|l|}{$C P$} \\
\hline 0 & $12.04 \mathrm{Aa}$ & $13.63 \mathrm{Aa}$ & $12.86 \mathrm{ABa}$ & 27.04 \\
\hline 45 & $7.78 \mathrm{Ba}$ & $7.74 \mathrm{Ba}$ & $9.15 \mathrm{Ba}$ & \\
\hline 90 & $12.16 \mathrm{Aa}$ & $8.23 \mathrm{Bb}$ & $11.23 \mathrm{Bab}$ & \\
\hline 180 & $9.79 \mathrm{ABb}$ & $15.70 \mathrm{Aa}$ & $17.32 \mathrm{Aa}$ & \\
\hline \multicolumn{5}{|l|}{$N D F$} \\
\hline 0 & $79.25 \mathrm{Aa}$ & $75.22 \mathrm{Ab}$ & $69.05 \mathrm{Cc}$ & 4.84 \\
\hline 45 & $78.52 \mathrm{Aab}$ & $76.62 \mathrm{Ab}$ & $81.60 \mathrm{Aa}$ & \\
\hline 90 & $71.41 \mathrm{Bb}$ & $73.41 \mathrm{Aab}$ & $75.62 \mathrm{Ba}$ & \\
\hline 180 & $71.38 \mathrm{Bb}$ & $75.15 \mathrm{Aa}$ & $72.99 \mathrm{Bab}$ & \\
\hline \multicolumn{5}{|l|}{$A D F$} \\
\hline 0 & $34.84 \mathrm{Aab}$ & $35.34 \mathrm{ABa}$ & $32.86 \mathrm{BCb}$ & 6.94 \\
\hline 45 & $37.28 \mathrm{Aa}$ & $33.47 \mathrm{Bb}$ & $35.52 \mathrm{Aab}$ & \\
\hline 90 & $30.32 \mathrm{Bb}$ & $30.91 \mathrm{Cb}$ & $34.13 \mathrm{ABa}$ & \\
\hline 180 & $31.69 \mathrm{Bb}$ & $36.81 \mathrm{Aa}$ & $31.22 \mathrm{Cb}$ & \\
\hline \multicolumn{5}{|l|}{ Ash } \\
\hline 0 & $6.67 \mathrm{ABb}$ & $6.19 \mathrm{Bb}$ & $11.38 \mathrm{Aa}$ & 37.55 \\
\hline 45 & $5.48 \mathrm{Ba}$ & $5.37 \mathrm{Ba}$ & $5.46 \mathrm{Ba}$ & \\
\hline 90 & $5.08 \mathrm{Ba}$ & $5.27 \mathrm{Ba}$ & $5.02 \mathrm{Ba}$ & \\
\hline 180 & $10.34 \mathrm{Aa}$ & $10.67 \mathrm{Aa}$ & $11.96 \mathrm{Aa}$ & \\
\hline
\end{tabular}

Note. For each parameter analyzed, means followed by different letters, in upper case in the same column and lower case in the same row are different according to the Tukey test $(\mathrm{P}<0.05)$.

As well as with the cultivar BRS 1501, the nitrogen dose did not influence the dry matter content of the ADR 500 treatments, which were only influenced by the height of the plant. At the heights of 0.80 and 0.90 the dose of $180 \mathrm{~kg} \mathrm{~N} \mathrm{ha}^{-1}$ promoted the highest crude protein levels. This $\mathrm{N}$ dose also promoted, at the height of $0.70 \mathrm{~m}$, a reduction in NDF and ADF, and an increase in ash content.

It was expected that the NDF contents increases according to plant height and decreases according to N fertilization. However, this did not occurred. When evaluating the nitrogen fertilization in pearl millet grazed by sheep, Amaral et al. (2017) did not observe effect of $\mathrm{N}$ fertilization on NDF contents.

For both cultivars the NDF content presented is considered high (Mertens, 1993). This compromises the voluntary intake due to increased rumen fill and extended time required to chew and reduce the particle size of fiber to enable passage from the rumen (Hammond et al., 2016).

\subsection{Ruminal Degradation}

The disappearance rates of the dry matter from the evaluated cultivars, in function of the nitrogen dose and cutting height, are presented in Table 4. 
Table 4. Disappearance rates of the dry matter from the evaluated cultivars, in function of the nitrogen dose and pre-cut height

\begin{tabular}{|c|c|c|c|c|c|c|c|c|c|c|c|c|}
\hline \multirow{6}{*}{ Time (h) } & \multicolumn{12}{|c|}{ BRS 1501} \\
\hline & \multicolumn{12}{|c|}{$\mathrm{N}$ dose $\left(\mathrm{kg} \mathrm{ha}^{-1}\right)$} \\
\hline & \multirow{2}{*}{\multicolumn{3}{|c|}{0}} & \multirow{2}{*}{\multicolumn{2}{|c|}{45}} & & \multicolumn{3}{|c|}{90} & \multicolumn{3}{|c|}{180} \\
\hline & & & & & & \multicolumn{4}{|c|}{ Cutting height (m) } & & & \\
\hline & 0.70 & 0.80 & 0.90 & 0.70 & 0.80 & 0.90 & 0.70 & 0.80 & 0.90 & 0.70 & 0.80 & 0.90 \\
\hline & \multicolumn{12}{|c|}{ Dry matter disappearance $(\%)$} \\
\hline \multirow[t]{2}{*}{0} & 27.67 & 26.42 & 26.95 & 25.93 & 26.74 & 23.57 & 28.04 & 27.60 & 26.84 & 29.29 & 29.82 & 31.23 \\
\hline & $\mathrm{Ca}$ & $\mathrm{Ca}$ & $\mathrm{Ca}$ & $\mathrm{Ba}$ & $\mathrm{Ba}$ & $\mathrm{Ca}$ & $\mathrm{Ca}$ & $\mathrm{Ba}$ & $\mathrm{Ba}$ & $\mathrm{Ca}$ & $\mathrm{Ca}$ & $\mathrm{Ca}$ \\
\hline \multirow[t]{2}{*}{12} & 30.33 & 34.10 & 29.60 & 28.55 & 28.74 & 27.14 & 30.56 & 29.38 & 28.59 & 32.61 & 35.89 & 32.27 \\
\hline & $\mathrm{Ca}$ & $\mathrm{BCa}$ & $\mathrm{BCa}$ & $\mathrm{Ba}$ & $\mathrm{Ba}$ & $\mathrm{Ba}$ & $\mathrm{BCa}$ & $\mathrm{Ba}$ & $\mathrm{Ba}$ & $\mathrm{Ca}$ & $\mathrm{BCa}$ & $\mathrm{BCa}$ \\
\hline \multirow[t]{2}{*}{24} & 34.12 & 38.91 & 35.60 & 31.06 & 33.27 & 33.01 & 33.82 & 34.77 & 31.64 & 45.10 & 40.72 & 35.96 \\
\hline & $\mathrm{BCab}$ & $\mathrm{BCa}$ & $\mathrm{BCab}$ & $\mathrm{Bb}$ & $\mathrm{Bab}$ & $\mathrm{Bab}$ & $\mathrm{BCab}$ & $\mathrm{Bab}$ & $\mathrm{Bab}$ & $\mathrm{Ba}$ & $\mathrm{Bab}$ & $\mathrm{Bab}$ \\
\hline \multirow[t]{2}{*}{48} & 44.49 & 50.06 & 45.21 & 40.39 & 43.51 & 40.12 & 39.67 & 43.33 & 52.36 & 57.14 & 47.27 & 58.32 \\
\hline & $\mathrm{ABab}$ & $\mathrm{ABab}$ & $\mathrm{ABab}$ & $\mathrm{ABb}$ & $\mathrm{ABab}$ & $\mathrm{Bb}$ & $\mathrm{ABb}$ & $\mathrm{ABab}$ & $\mathrm{Aab}$ & $\mathrm{Ba}$ & $\mathrm{Bab}$ & $\mathrm{Aa}$ \\
\hline \multirow[t]{4}{*}{96} & 56.27 & 62.20 & 56.59 & 57.80 & 62.31 & 54.61 & 52.37 & 55.92 & 61.86 & 77.53 & 70.37 & 64.39 \\
\hline & $\mathrm{Abc}$ & Aabc & $\mathrm{Abc}$ & $\mathrm{Abc}$ & Aabc & $\mathrm{Abc}$ & $\mathrm{Ac}$ & $\mathrm{Abc}$ & Aabc & $\mathrm{Aa}$ & $\mathrm{Aab}$ & Aabc \\
\hline & \multicolumn{12}{|c|}{ ADR 500} \\
\hline & \multicolumn{12}{|c|}{$\mathrm{N}$ dose $\left(\mathrm{kg} \mathrm{ha}^{-1}\right)$} \\
\hline \multirow{4}{*}{ Time (h) } & \multirow{2}{*}{\multicolumn{3}{|c|}{0}} & \multirow{2}{*}{\multicolumn{2}{|c|}{45}} & & \multicolumn{3}{|c|}{90} & \multirow{2}{*}{\multicolumn{3}{|c|}{180}} \\
\hline & & & & & & \multicolumn{4}{|c|}{ Cutting height (m) } & & & \\
\hline & 0.70 & 0.80 & 0.90 & 0.70 & 0.80 & 0.90 & 0.70 & 0.80 & 0.90 & 0.70 & 0.80 & 0.90 \\
\hline & \multicolumn{12}{|c|}{ Dry matter disappearance $(\%)$} \\
\hline \multirow[t]{2}{*}{0} & 24.23 & 31.41 & 26.79 & 29.79 & 27.41 & 27.03 & 29.73 & 27.62 & 31.37 & 24.16 & 27.64 & 28.53 \\
\hline & $\mathrm{Ca}$ & $\mathrm{Ba}$ & $\mathrm{Ca}$ & $\mathrm{Ba}$ & $\mathrm{Ca}$ & $\mathrm{Ca}$ & $\mathrm{Ba}$ & $\mathrm{Ca}$ & $\mathrm{Ba}$ & $\mathrm{Ca}$ & $\mathrm{Ca}$ & $\mathrm{Da}$ \\
\hline \multirow[t]{2}{*}{12} & 33.07 & 37.99 & 34.18 & 33.52 & 30.82 & 31.44 & 33.61 & 31.56 & 34.03 & 32.64 & 38.93 & 34.75 \\
\hline & $\mathrm{Ba}$ & $\mathrm{Ba}$ & $\mathrm{BCa}$ & $\mathrm{Ba}$ & $\mathrm{Ca}$ & $\mathrm{Ca}$ & $\mathrm{Ba}$ & $\mathrm{BCa}$ & $\mathrm{Ba}$ & $\mathrm{Ba}$ & $\mathrm{Ba}$ & $\mathrm{CDa}$ \\
\hline \multirow[t]{2}{*}{24} & 34.43 & 38.96 & 36.01 & 36.10 & 36.07 & 37.33 & 37.29 & 33.02 & 37.44 & 33.80 & 39.86 & 37.70 \\
\hline & $\mathrm{Ba}$ & $\mathrm{Ba}$ & $\mathrm{Ba}$ & $\mathrm{Ba}$ & $\mathrm{BCa}$ & $\mathrm{BCa}$ & $\mathrm{Ba}$ & $\mathrm{BCa}$ & $\mathrm{Ba}$ & $\mathrm{Ba}$ & $\mathrm{Ba}$ & $\mathrm{Ca}$ \\
\hline \multirow[t]{2}{*}{48} & 42.81 & 60.35 & 44.60 & 38.09 & 46.36 & 41.26 & 43.89 & 40.33 & 38.08 & 39.29 & 56.41 & 51.02 \\
\hline & $\mathrm{Bb}$ & $\mathrm{Aa}$ & $\mathrm{Bb}$ & $\mathrm{Bb}$ & $\mathrm{Ba}$ & $\mathrm{Bb}$ & $\mathrm{ABb}$ & $\mathrm{Bb}$ & $\mathrm{Bb}$ & $\mathrm{ABb}$ & $\mathrm{Aa}$ & $\mathrm{Ba}$ \\
\hline 96 & 67.84 & 71.83 & 64.06 & 59.58 & 62.56 & 54.28 & 52.47 & 55.13 & 58.88 & 47.82 & 69.33 & 70.45 \\
\hline & $\mathrm{Aa}$ & $\mathrm{Aa}$ & $\mathrm{Aab}$ & Aab & Aab & $\mathrm{Ab}$ & $\mathrm{Ab}$ & $A a b$ & $A a b$ & $\mathrm{Ab}$ & $\mathrm{Aa}$ & $\mathrm{Aa}$ \\
\hline
\end{tabular}

Note. Means followed by different upper letters in the column and lower case in the row are different between each other according to the Tukey test $(\mathrm{P}<0.05)$.

For the cultivar BRS 1501, nitrogen fertilization increased the DM disappearance rate only at the $180 \mathrm{~kg} \mathrm{~N} \mathrm{ha}^{-1}$ dose, at heights 0.70 and $0.80 \mathrm{~m}$, which disappeared after 96 hours of incubation, superior than other treatments. The combination of fertilization with $90 \mathrm{~kg} \mathrm{~N} \mathrm{ha}^{-1}$ and cut at $0.70 \mathrm{~m}$ decreased the dry matter disappearance rate of BRS 1501.

The dry matter disappearance rate of ADR 500 cultivar with pre-cut height of $0.90 \mathrm{~m}$ was positively influenced by nitrogen fertilization. This height was also the one that showed the higher difference of disappearance of MS between time 0 and 96 hours of incubation (44.92 percentage points).

In the Table 5 are presented the fractions $\mathrm{A}$ and $\mathrm{B}$ and the degradation rate of fraction $\mathrm{B}$ of the dry matter of cultivars BRS 1501 and ADR 500, fertilized with four doses of nitrogen, at three pre-cut heights. 
Table 5. Soluble fraction (A), potentially degradable fraction (B) and degradation rate of fraction B (c) of the dry matter from the cultivars BRS 1501 and ADR 500, submitted to pre-cut heights and nitrogen doses

\begin{tabular}{|c|c|c|c|c|c|c|c|c|c|}
\hline \multirow{3}{*}{$\mathrm{N}$ dose $\left(\mathrm{kg} \mathrm{ha}^{-1}\right)$} & \multicolumn{9}{|c|}{ BRS 1501} \\
\hline & \multicolumn{3}{|c|}{$\mathrm{A}(\%)$} & \multicolumn{3}{|c|}{$\mathrm{B}(\%)$} & \multicolumn{3}{|c|}{$\mathrm{c}\left(\% \mathrm{~h}^{-1}\right)$} \\
\hline & 0.70 & 0.80 & 0.90 & 0.70 & 0.80 & 0.90 & 0.70 & 0.80 & 0.90 \\
\hline 0 & 27.67 & 26.42 & 26.95 & 28.60 & 35.78 & 29.65 & 1.92 & 2.77 & 2.11 \\
\hline 45 & 25.93 & 26.74 & 23.57 & 31.86 & 35.57 & 31.04 & 1.30 & 1.35 & 1.64 \\
\hline 90 & 28.22 & 28.13 & 26.84 & 24.15 & 27.80 & 35.02 & 1.43 & 1.80 & 2.99 \\
\hline 180 & 29.44 & 29.82 & 31.23 & 48.09 & 40.55 & 33.16 & 1.61 & 0.91 & 3.53 \\
\hline \multirow{3}{*}{$\mathrm{N}$ dose $\left(\mathrm{kg} \mathrm{ha}^{-1}\right)$} & \multicolumn{9}{|c|}{ ADR 500} \\
\hline & \multicolumn{3}{|c|}{$\mathrm{A}(\%)$} & \multicolumn{3}{|c|}{ B (\%) } & \multicolumn{3}{|c|}{$\mathrm{c}\left(\% \mathrm{~h}^{-1}\right)$} \\
\hline & 0.70 & 0.80 & 0.90 & 0.70 & 0.80 & 0.90 & 0.70 & 0.80 & 0.90 \\
\hline 0 & 24.23 & 31.41 & 26.79 & 43.61 & 40.42 & 37.26 & 1.12 & 3.06 & 1.37 \\
\hline 45 & 29.79 & 27.41 & 27.03 & 29.79 & 35.14 & 27.25 & 0.85 & 1.65 & 1.62 \\
\hline 90 & 29.73 & 27.62 & 31.73 & 22.73 & 27.50 & 25.51 & 2.25 & 1.32 & 0.59 \\
\hline 180 & 24.16 & 27.64 & 28.53 & 23.66 & 41.68 & 41.92 & 2.11 & 2.41 & 1.87 \\
\hline
\end{tabular}

The use of $180 \mathrm{~kg} \mathrm{ha}^{-1}$ of nitrogen with nitrification inhibitor promoted an increase in the DM degradability of both cultivars at $0.90 \mathrm{~m}$, and also in cv. BRS 1501 at $0.70 \mathrm{~m}$ height (Table 6). In the fertilized treatments, the height of $0.90 \mathrm{~m}$ presented, in general, better degradability. This is probably due to the better absorption of nitrogen at this time. The product used has $54.17 \%$ nitrogen in the ammonium form $\left(\mathrm{NH}_{4}{ }^{+}\right)$and $45.83 \%$ in the form of nitrate $\left(\mathrm{NO}_{3}{ }^{-}\right)$, and the effect of nitrification inhibition lasts from four to ten weeks, depending on the climatic conditions ("Compo Expert", 2013).

Table 6. Effective ruminal degradability of the dry matter from the cultivars BRS 1501 and ADR 500, submitted to pre-cut heights and nitrogen doses

\begin{tabular}{|c|c|c|c|c|c|c|}
\hline \multirow{3}{*}{$\mathrm{N}$ dose $\left(\mathrm{kg} \mathrm{ha}^{-1}\right)$} & \multicolumn{6}{|c|}{ Ruminal degradability at $5 \%$ passage rate } \\
\hline & \multicolumn{3}{|c|}{ BRS 1501} & \multicolumn{3}{|c|}{ ADR 500} \\
\hline & 0.70 & 0.80 & 0.90 & 0.70 & 0.80 & 0.90 \\
\hline 0 & $35.57 \mathrm{Ba}$ & $38.08 \mathrm{Aa}$ & $35.63 \mathrm{Ca}$ & $32.06 \mathrm{Bb}$ & $45.78 \mathrm{Aa}$ & $34.55 \mathrm{Bb}$ \\
\hline 45 & $32.47 \mathrm{Ba}$ & $34.27 \mathrm{Ba}$ & $31.21 \mathrm{Da}$ & $33.31 \mathrm{ABa}$ & $36.21 \mathrm{Ba}$ & $33.54 \mathrm{Ba}$ \\
\hline 90 & $33.26 \mathrm{Bb}$ & $35.33 \mathrm{ABb}$ & $39.60 \mathrm{Ba}$ & $36.46 \mathrm{Aa}$ & $33.21 \mathrm{Ba}$ & $34.22 \mathrm{Ba}$ \\
\hline 180 & $39.69 \mathrm{Ab}$ & $35.34 \mathrm{ABc}$ & $44.96 \mathrm{Aa}$ & $30.98 \mathrm{Bb}$ & $41.07 \mathrm{Aa}$ & $38.92 \mathrm{Aa}$ \\
\hline
\end{tabular}

Note. Means followed by different upper letters in the column and lower case in the row, for the same cultivar, are different between each other according to the Tukey test $(\mathrm{P}<0.05)$.

In the Table 7 are presented the availabilities in $\mathrm{kg} \mathrm{ha}^{-1}$ of nitrogen in ammonium and nitrate forms, from the fertilizer.

Table 7. Availability $\left(\mathrm{kg} \mathrm{ha}^{-1}\right)$ of nitrogen in ammonium $\left(\mathrm{NH}_{4}{ }^{+}\right)$and nitrate $\left(\mathrm{NO}_{3}{ }^{-}\right)$forms, in function of the fertilizer dose used

\begin{tabular}{lll}
\hline \multirow{2}{*}{ N dose $\left(\mathrm{kg} \mathrm{ha}^{-1}\right)$} & \multicolumn{2}{c}{ Nitrogen available form } \\
\cline { 2 - 3 } & ${\mathrm{N}-\mathrm{NH}_{4}^{+}\left(\mathrm{kg} \mathrm{ha}^{-1}\right)}^{-\mathrm{NO}_{3}^{-}\left(\mathrm{kg} \mathrm{ha}^{-1}\right)}$ \\
\hline 45 & 24.37 & 20.63 \\
90 & 48.74 & 41.26 \\
180 & 97.48 & 85.52 \\
\hline
\end{tabular}

Studies conducted by Silva, Couto, and Santos (2010) and Britto and Kronzucker (2002) showed that the absorption of high amounts of $\mathrm{NH}_{4}{ }^{+}$can be detrimental to plants, causing $\mathrm{H}^{+}$excess, which decreases the cytoplasmic $\mathrm{pH}$ and generates acidity in the tissues, provoking intoxication symptoms. Thus, there is a need to 
use the carbohydrates produced for the assimilation of the absorbed ammonium, in order to avoid its accumulation and consequent toxicity problems related to changes in cellular $\mathrm{pH}$ and ion imbalance (Britto \& Kronzucker, 2002).

Therefore, it can be inferred that when 45 or $90 \mathrm{~kg} \mathrm{~N} \mathrm{ha}^{-1}$ were applied, there were low concentrations of nitrogen, both in the form of ammonium (more easily assimilable form) as in the form of nitrate (less toxic form) to the plants, but with a higher concentration of $\mathrm{NH}_{4}{ }^{+}$, which impaired the performance, in degradability terms, of the plants cut at lower heights. Because they are cut younger, the roots of these plants did not find nitrate concentrations that favored their absorption, having to choose ammonium and, with that, having to mobilize their reserves of carbon, hydrogen and oxygen, to produce carbohydrates instead of protein, with the aim of neutralizing the harmful effects of excess ammonium in the organism. An experiment was conducted by Cui et al (2017) and the authors verify that the grasses evaluated (Forage Oat and Highland Barley) showed a preference for ammonium absorption during early growth stages, but, in the later stages, the preference was for $\mathrm{NO}_{3}{ }^{-}$. According to Bittsánszky et al. (2015) the ammonium toxicity typically occurs when the plant is exposed to high environmental concentrations of this chemical and the results of the intoxication, among others, are: depletion of carbon supply, damaged chloroplast ultrastructure, deficiency of mineral cations, disruptions in hormonal homeostasis and in photosynthesis. This can be confirmed by the high levels of NDF and low CP (Tables 2 and 3 ) found in the treatments with the lowest cutting heights $(0.70$ and $0.80 \mathrm{~m})$ and lower $\mathrm{N}$ doses $\left(45 \mathrm{and} 90 \mathrm{~kg} \mathrm{ha}{ }^{-1}\right)$.

Table 8 shows the degradation parameters of the crude protein from the cultivars.

Table 8. Soluble fraction (A), potentially degradable fraction (B) and degradation rate of fraction B (c) of the crude protein from the cultivars BRS 1501 and ADR 500, submitted to pre-cut heights and nitrogen doses

\begin{tabular}{|c|c|c|c|c|c|c|c|c|c|}
\hline \multirow{3}{*}{$\mathrm{N}$ dose $\left(\mathrm{kg} \mathrm{ha}^{-1}\right)$} & \multicolumn{9}{|c|}{ BRS 1501} \\
\hline & \multicolumn{3}{|c|}{$\mathrm{A}(\%)$} & \multicolumn{3}{|c|}{$\mathrm{B}(\%)$} & \multicolumn{3}{|c|}{$\mathrm{c}\left(\% \mathrm{~h}^{-1}\right)$} \\
\hline & 0.70 & 0.80 & 0.90 & 0.70 & 0.80 & 0.90 & 0.70 & 0.80 & 0.90 \\
\hline 0 & 32.20 & 1.72 & 7.94 & 24.87 & 52.16 & 35.97 & 2.27 & 3.52 & 3.05 \\
\hline 45 & 23.56 & 19.99 & 27.99 & 38.11 & 37.51 & 21.29 & 1.50 & 3.16 & 1.65 \\
\hline 90 & 20.34 & 13.18 & 37.23 & 38.89 & 48.25 & 29.01 & 1.80 & 3.06 & 3.22 \\
\hline 180 & 25.61 & 26.61 & 36.78 & 56.24 & 52.92 & 38.72 & 2.14 & 1.66 & 2.15 \\
\hline \multirow{3}{*}{$\mathrm{N}$ dose $\left(\mathrm{kg} \mathrm{ha}^{-1}\right)$} & \multicolumn{9}{|c|}{ ADR 500} \\
\hline & \multicolumn{3}{|c|}{$\mathrm{A}(\%)$} & \multicolumn{3}{|c|}{ B (\%) } & \multicolumn{3}{|c|}{$\mathrm{c}\left(\% \mathrm{~h}^{-1}\right)$} \\
\hline & 0.70 & 0.80 & 0.90 & 0.70 & 0.80 & 0.90 & 0.70 & 0.80 & 0.90 \\
\hline 0 & 21.57 & 34.01 & 39.41 & 51.90 & 35.28 & 38.73 & 1.37 & 2.68 & 1.85 \\
\hline 45 & 26.64 & 33.99 & 10.24 & 55.23 & 45.16 & 52.87 & 1.38 & 2.37 & 2.95 \\
\hline 90 & 35.43 & 8.82 & 28.32 & 37.24 & 63.96 & 32.25 & 3.01 & 1.73 & 2.42 \\
\hline 180 & 17.42 & 30.63 & 40.16 & 55.91 & 31.07 & 35.97 & 1.19 & 5.09 & 2.17 \\
\hline
\end{tabular}

The degradability varied, in the cultivar BRS 1501, from $27.65 \%\left(90 \mathrm{~kg} \mathrm{~N} \mathrm{ha}^{-1}, 0.70 \mathrm{~m}\right)$ to $48.12 \%(180 \mathrm{~kg} \mathrm{~N}$ $\left.\mathrm{ha}^{-1}, 0.90 \mathrm{~m}\right)$ and in the cv. ADR 500, from 25.08\% (90 kg N ha $\left.{ }^{-1}, 0.80 \mathrm{~m}\right)$ to $51.07 \%\left(180 \mathrm{~kg} \mathrm{~N} \mathrm{ha}^{-1}, 0.90 \mathrm{~m}\right)$. The parameter "B", potentially degradable fraction, ranged from $21.29 \%$ (45 kg N ha-1, $0.90 \mathrm{~m})$ to 56.24 (180 kg $\left.\mathrm{N} \mathrm{ha}^{-1}, 0.70 \mathrm{~m}\right)$ in the BRS 1501 cultivar, and from $31.07 \%\left(180 \mathrm{~kg} \mathrm{~N} \mathrm{ha}^{-1}, 0.80 \mathrm{~m}\right)$ to $63.96 \%\left(90 \mathrm{~kg} \mathrm{~N} \mathrm{ha}^{-1}\right.$, $0.80 \mathrm{~m}$ ) in the cv. ADR 500. This result is unexpected, since the treatment with $90 \mathrm{~kg} \mathrm{~N} \mathrm{ha}{ }^{-1}, 0.80 \mathrm{~m}$, of cultivar ADR 500, was the one who had lower effective degradability. To this treatment, the estimated potential degradability was $72.78 \%$. The values of the soluble fraction "A" are below than the found by Prado et al. (2004), of $43.0 \%$. 
Table 9. Effective ruminal degradability of the crude protein from the cultivars BRS 1501 and ADR 500, submitted to pre-cut heights and nitrogen doses

\begin{tabular}{|c|c|c|c|c|c|c|}
\hline \multirow{3}{*}{$\mathrm{N}$ dose $\left(\mathrm{kg} \mathrm{ha}^{-1}\right)$} & \multicolumn{6}{|c|}{ Ruminal degradability at $5 \%$ passage rate } \\
\hline & \multicolumn{3}{|c|}{ BRS 1501} & \multicolumn{3}{|c|}{ ADR 500} \\
\hline & 0.70 & 0.80 & 0.90 & 0.70 & 0.80 & 0.90 \\
\hline 0 & $39.24 \mathrm{Aa}$ & $34.94 \mathrm{Aa}$ & $35.76 \mathrm{Ba}$ & $31.40 \mathrm{BCb}$ & $45.86 \mathrm{Aa}$ & $48.90 \mathrm{Aa}$ \\
\hline 45 & $32.62 \mathrm{Ba}$ & $30.42 \mathrm{Ba}$ & $33.13 \mathrm{Ba}$ & $38.31 \mathrm{Bb}$ & $48.52 \mathrm{Aa}$ & $27.51 \mathrm{Cc}$ \\
\hline 90 & $27.65 \mathrm{Bb}$ & $30.04 \mathrm{Bb}$ & $47.94 \mathrm{Aa}$ & $49.27 \mathrm{Aa}$ & $25.08 \mathrm{Bc}$ & $38.85 \mathrm{Bb}$ \\
\hline 180 & $42.38 \mathrm{Aab}$ & $39.90 \mathrm{Ab}$ & $48.12 \mathrm{Aa}$ & $28.16 \mathrm{Cb}$ & $46.31 \mathrm{Aa}$ & $51.07 \mathrm{Aa}$ \\
\hline
\end{tabular}

Note. Means followed by different upper letters in the column and lower case in the row, for the same cultivar, are different between each other according to the Tukey test $(\mathrm{P}<0.05)$.

There might have been microbial contamination, which contributed to decrease the values of effective degradability of CP (Brunette, Baurhoo, \& Mustafa, 2014).

Contamination tends to be higher in foods with lower protein and higher fiber contents, increasing, in a non-linear way, the incubation time (Nocek, 1988), which may reach $67.2 \%$ of the CP measured by conventional methods after ruminal incubation (Rodríguez, Gonzáles, Aivir, \& Caballero, 2008). According to Gonzáles, Ouarti, Rodríguez, and Alvir (2006), 58.6\% of the undegradable protein fraction of forage would actually be protein of microbial origin.

The fact of forming a pool of samples from successive cuts (four for ADR 500 fertilized with $180 \mathrm{~kg} \mathrm{~N} \mathrm{ha}^{-1}$ and three for the remaining) may also have contributed to the low degradability of the protein from the forage analyzed, due to the increase of the protein fractions $\mathrm{B}_{2}$ and $\mathrm{B}_{3}$, that occurs when successive cuts are made (Faria Júnior et al., 2013). The increase of these fractions decreases the ruminal degradation rate of the protein, since they are considered as fractions of medium and slow degradation (Sniffen et al., 1992).

The degradation parameters of the neutral detergent insoluble fiber (NDF) of the two cultivars are shown in Table 10 .

Table 10. Soluble fraction (A), potentially degradable fraction (B) and degradation rate of fraction B (c) of the neutral detergent insoluble fiber from the cultivars BRS 1501 and ADR 500, submitted to pre-cut heights and nitrogen doses

\begin{tabular}{|c|c|c|c|c|c|c|c|c|c|}
\hline \multirow{3}{*}{$\mathrm{N}$ dose $\left(\mathrm{kg} \mathrm{ha}^{-1}\right)$} & \multicolumn{9}{|c|}{ BRS 1501} \\
\hline & \multicolumn{3}{|c|}{$\mathrm{A}(\%)$} & \multicolumn{3}{|c|}{$\mathrm{B}(\%)$} & \multicolumn{3}{|c|}{$\mathrm{c}\left(\% \mathrm{~h}^{-1}\right)$} \\
\hline & 0.70 & 0.80 & 0.90 & 0.70 & 0.80 & 0.90 & 0.70 & 0.80 & 0.90 \\
\hline 0 & 35.02 & 32.69 & 27.21 & 18.10 & 27.66 & 26.04 & 1.67 & 2.66 & 2.43 \\
\hline 45 & 16.84 & 30.57 & 32.33 & 38.96 & 26.31 & 20.68 & 1.99 & 2.47 & 2.59 \\
\hline 90 & 36.71 & 31.70 & 31.23 & 16.34 & 22.64 & 30.45 & 1.96 & 1.67 & 3.14 \\
\hline 180 & 31.67 & 31.37 & 26.45 & 44.55 & 38.14 & 32.58 & 2.04 & 1.21 & 3.63 \\
\hline \multirow{3}{*}{$\mathrm{N}$ dose $\left(\mathrm{kg} \mathrm{ha}^{-1}\right)$} & \multicolumn{9}{|c|}{ ADR 500} \\
\hline & \multicolumn{3}{|c|}{$\mathrm{A}(\%)$} & \multicolumn{3}{|c|}{ B (\%) } & \multicolumn{3}{|c|}{$\mathrm{c}\left(\% \mathrm{~h}^{-1}\right)$} \\
\hline & 0.70 & 0.80 & 0.90 & 0.70 & 0.80 & 0.90 & 0.70 & 0.80 & 0.90 \\
\hline 0 & 26.02 & 22.55 & 8.20 & 42.30 & 49.04 & 52.55 & 0.86 & 2.91 & 1.79 \\
\hline 45 & 26.83 & 27.53 & 31.54 & 33.10 & 42.78 & 35.01 & 2.15 & 0.81 & 0.97 \\
\hline 90 & 25.57 & 28.84 & 25.10 & 42.48 & 33.54 & 34.13 & 0.72 & 0.56 & 0.79 \\
\hline 180 & 22.56 & 23.02 & 27.21 & 45.47 & 45.09 & 30.19 & 0.83 & 2.37 & 1.81 \\
\hline
\end{tabular}

The higher values of potential degradability, for each cultivar, were from $76.22 \%\left(180 \mathrm{~kg} \mathrm{~N} \mathrm{ha}^{-1}, 0.70 \mathrm{~m}\right)$ to BRS 1501 cultivar, and $71.59 \%(0 \mathrm{~N}, 0.80 \mathrm{~m})$ to ADR 500 . The mean value for each cultivar was of $58.85 \%$ to the BRS 1501 and $65.05 \%$ to the ADR 500. For peal millet pasture, Prado et al. (2004) found potential degradability of $71.8 \%$. 
Table 11. Effective ruminal degradability of the neutral detergent insoluble fiber from the cultivars BRS 1501 and ADR 500, submitted to pre-cut heights and nitrogen doses

\begin{tabular}{|c|c|c|c|c|c|c|}
\hline \multirow{3}{*}{$\mathrm{N}$ dose $\left(\mathrm{kg} \mathrm{ha}^{-1}\right)$} & \multicolumn{6}{|c|}{ Ruminal degradability at $5 \%$ passage rate } \\
\hline & \multicolumn{3}{|c|}{ BRS 1501} & \multicolumn{3}{|c|}{ ADR 500} \\
\hline & 0.70 & 0.80 & 0.90 & 0.70 & 0.80 & 0.90 \\
\hline 0 & $39.52 \mathrm{Ba}$ & $41.17 \mathrm{Aa}$ & $35.74 \mathrm{Bb}$ & $31.80 \mathrm{Bb}$ & $40.30 \mathrm{Aa}$ & $29.85 \mathrm{Bb}$ \\
\hline 45 & $28.23 \mathrm{Cb}$ & $38.68 \mathrm{ABa}$ & $38.34 \mathrm{Ba}$ & $35.95 \mathrm{Aa}$ & $33.95 \mathrm{Ba}$ & $36.36 \mathrm{Aa}$ \\
\hline 90 & $41.29 \mathrm{ABa}$ & $37.22 \mathrm{Bb}$ & $42.57 \mathrm{Aa}$ & $31.04 \mathrm{Ba}$ & $31.66 \mathrm{Ba}$ & $29.68 \mathrm{Ba}$ \\
\hline 180 & $44.07 \mathrm{Aa}$ & $38.56 \mathrm{ABb}$ & $40.17 \mathrm{ABab}$ & $30.20 \mathrm{Bb}$ & $37.36 \mathrm{ABa}$ & $35.22 \mathrm{Aa}$ \\
\hline
\end{tabular}

Note. Means followed by different upper letters in the column and lower case in the row, for the same cultivar, are different between each other according to the Tukey test $(\mathrm{P}<0.05)$.

The NDF levels found were high, and this could have harmed its degradation, because according to Mertens (1993), high concentrations of NDF in the plant indicate the thickening of the cell wall and greater resistance, both to the rupture by the chewing of the animal, but mainly to microbial penetration, which reduces the surface area for microbial attack, thus reducing the degradability of the NDF fraction itself. However, the NDF degradability found in this study are not inferior to those seen in other studies, such as Prado et al. (2004), who reported a degradability of $34.8 \%$ for millet NDF with the plants having $61.38 \%$ NDF in the dry matter; or Brunette et al. (2014), which verified $32.5 \%$ of NDF degradability, with a passage rate of $6.25 \% \mathrm{~h}^{-1}$, with the plant presenting $58.4 \%$ of NDF.

The results suggest, through potential degradability, that if the incubation time would have been elongated, the cultivars might have presented higher effective degradability, at the nitrogen doses and heights analyzed.

A study was conducted by Dong et al. (2017) and evaluated the two methods for incubating nylon bags in the rumen which are: placing the nylon bags in the rumen simultaneously and retrieving them at different time points or inserting nylon bags into the rumen at different time points and withdraw simultaneously (method used here). The authors verified that the effective degradability of dry matter, crude protein and NDF of the evaluated feeds (corn silage, alfalfa haylage, corn and soybean) were higher when the nylon bags were placed simultaneously and retried at different time points. In the NDF degradability, the difference between the two methods reached $11 \%$. Thus, the method used in our study (inserting nylon bags into the rumen at different time points and withdraw simultaneously) could contributed to the low NDF degradability presented. This occurs because the digestion process is often interrupted when bags are retrieved and then reinserted into the rumen to the insertion of the new bags (smaller incubation times) (Dong et al., 2017).

\section{Conclusion}

Nitrogen fertilization with nitrification inhibitor in high doses raises the degradability of dry matter, crude protein and neutral detergent insoluble fiber of millet managed at $0.90 \mathrm{~m}$.

The combination of fertilization with 45 and $90 \mathrm{~kg} \mathrm{ha}^{-1}$ of nitrogen with nitrification inhibitor, with the handling of millet at 0.70 or $0.80 \mathrm{~m}$ did not favor the nutritional quality (composition and degradability) of forage indicating that, in these treatments, the relationship between nitrogen availability in ammonium and nitrate forms may have been detrimental to plants.

\section{References}

Amaral, G. A., David, D. B., Gere, J. I., Savian, J. V., Kohmann, M. M., Nadin, L. B., ... Carvalho, P. C. F. (2016). Methane emissions from sheep grazing pearl millet (Penissetum americanum (L.) Leeke) swards fertilized with increasing nitrogen levels. Small Ruminant Research, 141, 118-123. https://doi.org/10.1016/ j.smallrumres.2016.07.011

Association of Official Analytical Chemists. (1990). Official methods of analysis (15th ed.). Washington, WA: AOAC; 1990.

Bittsánszky, A., Pilinszky, K., Gyulai, G., \& Komives, T. (2015). Overcoming ammonium toxicity. Plant Science, 231, 184-190. https://doi.org/10.1016/j.plantsci.2014.12.005

Bredemeier, C., \& Mundstock, C. M. (2000). Regulation of nitrogen absorption and assimilation in plants. Ciência Rural, 30(2), 365-372. https://doi.org/10.1590/S0103-84782000000200029 
Brito, R. M., Sampaio, A. A. M., Fernandes, A. R. M., Henrique, W., Cattelan, J. W., \& Routman, K. S. (2007). In situ degradability and ruminal parameters by bovines fed diets balanced for different weight gains and potential of microbial fermentation. Revista Brasileira de Zootecnia, 36(Supl. 5), 1639-1650. https://oi.org/10.1590/S1516-35982007000700024

Britto, D. T., \& Kronzucker, H. J. (2002). $\mathrm{NH}_{4}{ }^{+}$toxicity in higher plants: A critical review. Journal of Plant Physiology, 159, 567-584. https://doi.org/10.1078/0176-1617-0774

Britto, D. T., \& Kronzucker, H. J. (2013). Ecological significance and complexity of N-source preference in plants. Annals of Botany, 112, 957-963. https://doi.org/10.1093/aob/mct157

Brunette, T., Baurhoo, B., \& Mustafa, A. F. (2014). Replacing corn silage with different forage millet silage cultivars: effects on milk yield, nutrient digestion, and ruminal fermentation of lactating dairy cows. Journal of Dairy Science, 97, 6440-6449. https://doi.org/10.3168/jds.2014-7998

Buso, W. H. D., França, A. F. S., \& Miyagi, E. S. (2014). Bromatological composition and dry matter digestibility of millet cultivars subjected to nitrogen doses. Arquivo Brasileiro de Medicina Veterinária e Zootecnia, 66, 887-893. https://doi.org/10.1590/1678-41626746

Cameron, K. C., Di, H. J., \& Moir, J. L. (2013). Nitrogen losses from the soil/plant system: A review. Annals of Applied Biology, 162, 145-173. https://doi.org/10.1111/aab.12014

Chen, D., Suter H. C., Islam, A., \& Edis, R. (2010). Influence of nitrification inhibitors on nitrification and nitrous oxide $\left(\mathrm{N}_{2} \mathrm{O}\right)$ emission from a clay loam soil fertilized with urea. Soil Biology \& Biochemistry, 42, 660-664. https://doi.org/10.1016/j.soilbio.2009.12.014

Compo Expert. (2013). Technical Information on NovaTec ${ }^{\circledR}$ N-Max 24-5-5. Münster, Germany. Retrieved February 8, 2015, from http://www.compo-expert.com/fileadmin/user_upload/compo_expert/en/documents/ pdf/product-information_2014/TI_NovaTec_N-Max_24-5-5.pdf

Cui, J., Yu, C., Qiao, N., Xu, X., Tian, Y., \& Ouyang, H. (2017). Plant preference for $\mathrm{NH}_{4}{ }^{+}$versus $\mathrm{NO}_{3}{ }^{-}$at different growth stages in analpine agroecosystem. Field Crops Research, 201, 192-199. https://doi.org/ 10.1016/j.fcr.2016.11.009

Dong, S., Azarfar, A., Zou, Y., Li, S., Wang, Y., \& Cao, Z. (2017). Effects of sequence of nylon bags rumen incubation on kinetics of degradation in some commonly used feedstuffs in dairy rations. Journal of Integrative Agriculture, 16, 162-168. https://doi.org/10.1016/S2095-3119(16)61438-7

Embrapa/CNPMS. (2014). Cultivo do Milheto. Sete Lagoas: EMBRAPA-CNPMS. Sistemas de produção 3. Retrieved February 1, 2015, from http://www.spo.cnptia.embrapa.br/expediente?p_p_id=expedienteportlet_ WAR_sistemasdeproducaolf6_1galceportlet\&p_p_lifecycle $=0 \& p \_p \_s t a t e=$ normal\&p_p_mode $=v i e w \& p \_p$ _col_id=column-3\&p_p_col_pos $=2 \& p \_p \_c o l \_c o u n t=7 \& p \_r$ _p_-76293187_sistemaProducaold $=3833 \&$ _ex pedienteportlet_WAR_sistemasdeproducaolf6_1galceportlet_redirect $=\mathrm{https} \% 3 \mathrm{~A} \% 2 \mathrm{~F} \% 2 \mathrm{Fwww}$. spo.cnptia.e mbrapa.br\%2Fconteudo\%3Fp_p_id\%3Dconteudoportlet_WAR_sistemasdeproducaolf6_1galceportlet $\% 26 \mathrm{p}$ _p_lifecycle\%3D0\%26p_p_state\%3Dnormal\%26p_p_mode\%3Dview\%26p_p_col_id $\% 3$ Dcolumn-1\%26p_ p_col_count\%3D1\%26p_r_p_-76293187_sistemaProducaoId\%3D3833\%26p_r_p_-996514994_topicoId\%3 D3849

Faria Júnior, O. L., França, A. F. S., Silva-Pause, A. G., Miyagi, E. S., Peron, H. J. M. C., Arnhold, E., ... Corrêa, D. S. (2013). Proteins fractions of pearl millet submitted to different nitrogen doses and cutting ages. Journal of Agricultural Studies, 1, 30-40. https://doi.org/10.5296/jas.v1i1.2890

Gilsanz, C., Báez, D., Misselbrook, T. H., Dhanoa, M. S., \& Cárdenas, L. M. (2016). Development of emission factors and efficiency of two nitrification inhibitors, DCD and DMPP. Agriculture, Ecosystems and Environment, 216, 1-8. https://doi.org/10.1016/j.agee.2015.09.030

Gonzáles, J., Ouarti, M., Rodríguez, C. A., \& Alvir, M. R. (2006). Effects of considering the rate of comminution of particles and microbial contamination on accuracy of in situ studies of feed protein degradability in ruminants. Animal Feed Science \& Technology, 125, 89-98. https://doi.org/10.1016/j.anifeedsci.2005.05.013

Hammond, K. J., Jones, A. K., Humphries, D. J., Crompton, L. A., \& Reynolds, C. K. (2016). Effects of diet forage source and neutral detergent fiber content on milk production of dairy cattle and methane emissions determined using GreenFeed and respiration chamber techniques. Journal of Dairy Science, 99, 7904-7917. https://doi.org/10.3168/jds.2015-10759 
Intergovernmental Panel on Climate Change (IPCC). (2001). Climate change 2001: The scientific basis. In J. T. Houghton, Y. Ding, M. Noguer, P. J. Van Der Linden, X. Dai, \& K. Maskell (Eds.), Contribution of working group I to the third assessment report of the intergovernmental panel on climate change (pp. 1-83) Cambridge: Cambridge University Press.

Martha Júnior, G. B., Vilela, L., \& Sousa, D. M. G. (Eds.). (2007). Cerrado: Uso eficiente de corretivos e fertilizantes em pastagens. Planaltina, DF: Embrapa Cerrados.

Mertens, D. R. (1993). Kinetics of cell wall digestion and passage in ruminant. In H. G. Jung, D. R. Buxton, R. D. Hatifield, D. R. Mertens, J. Ralph, \& P. J. Weimer (Eds.), Forage cell wall structure and digestibility (pp. 535-570). Madison, WI: America Society of Agronomy; Crop Science Society of America; Soil Science Society America.

Ministerio da Agricultura Pecuária e Abastecimento. (1992). Normais Climatológicas: 1961-1990. Brasilia, DF: MAPA.

Nocek, J. E. (1988). In situ and other methods to estimate ruminal protein and energy digestibility: A review. Journal of Dairy Science, 71, 2051-2069. https://doi.org/10.3168/jds.S0022-0302(88)79781-7

Orskov, E. R., \& Mcdonald, I. (1979). The estimation of protein degradability in the rumen from incubation measurements weighted according to rate passage. The Journal of Agricultural Science, 92, 499-503. https://doi.org/10.1017/S0021859600063048

Prado, I. N., Moreira, F. B., Zeoula, L. M., Wada, F. Y., Mizubuti, I. Y., \& Neves, C. A. (2004). In situ dry matter, crude protein, and neutral detergent fiber degradability of some grasses in continuous grazing. Revista Brasileira de Zootecnia, 33, 1333-1339. https://doi.org/10.1590/S1516-35982004000500027

Robertson, J. B., \& Van Soest, P. J. (1981). The detergent system of analysis and its application to human foods. In W. P. T. James \& O. Theander (Eds.), The analysis of dietary fiber in food (pp. 123-158). New York, NY: Marcel Dekker.

Rodríguez, C. A., Gonzáles, J., Alvir, M. R., \& Caballero, R. (2008). Effects of feed intake on in situ rumen microbial contamination and degradation of feeds. Livestock Science, 116, 108-117. https://doi.org/10.1016/ j.livsci.2007.09.013

Silva, A. G., Faria Júnior, O. L., França, A. F. S., Miyagi, E. S., Rios, L. C., Moraes Filho, C. G., \& Ferreira, J. L. (2012). Forage yield and chemical composition of pearl millet under nitrogen fertilization. Ciência Animal Brasileira, 13(1), 67-75. https://doi.org/10.5216/cab.v13i1.1434

Silva, D. J., \& Queiroz, A. C. (2002). Análise de alimentos: Métodos químicos e biológicos (3rd ed.). Viçosa, MG: UFV.

Silva, P. C. C., Couto, J. L., \& Santos, A. R. (2010) Absorption of nitrate and ammonium ions and its effects on the development of sunflower in nutrient solution. Revista de Biologia e Ciências da Terra, 10, 97-104.

Sniffen, C. J., Connor, J. D., Van Soest, P., Fox, D. G., \& Russel, J. B. (1992). A net carbohydrate and protein system for evaluating cattle diets: II. carbohydrate and protein availability. Journal of Animal Science, 70, 3562-3577. https://doi.org/10.2527/1992.70113562x

Trenkel, M. E. (1997). Improving Fertilizer use Efficiency: Controlled-release and stabilized fertilizers in agriculture. Paris: IFA.

Van Soest, P. J. (1994). Nutritional ecology of the ruminants. Ithaca, NY: Cornell University Press.

\section{Copyrights}

Copyright for this article is retained by the author(s), with first publication rights granted to the journal.

This is an open-access article distributed under the terms and conditions of the Creative Commons Attribution license (http://creativecommons.org/licenses/by/4.0/). 